\title{
KeMAMPUAN PEMECAHAN MaSalah Matematis dan SiKaP SiSWA TERHAdAP MODEL PEMBELAJARAN KOOPERATIF TIPE AIR DAN PRobing-Prompting
}

\author{
Mathematical Problem SkILl AND StUdents' Attitude towards \\ Cooperative Learning Model AIR and Probing-Prompting Type
}

\author{
Gina Nur Azizah ${ }^{1}$ dan Rostina Sundayana ${ }^{2}$ \\ ${ }^{1,2}$ Pendidikan Matematika, STKIP Garut \\ Garut, Jawa Barat, Indonesia \\ ginanurazizah94@gmail.com \\ r.sundayana@yahoo.co.id
}

\begin{abstract}
Abstrak
Matematika masih dianggap sulit bagi kebanyakan siswa. Hal itu menyebabkan kemampuan pemecahan masalah matematis siswa masih rendah. Salah satu penyebabnya adalah penerapan model pembelajaran yang kurang tepat. Tujuan penelitian ini untuk mengkaji perbedaan pencapaian dan kualitas peningkatan kemampuan pemecahan masalah matematis serta sikap siswa antara siswa yang mendapatkan model pembelajaran kooperatif tipe Auditory Intellectually Repetition (AIR) dengan tipe Probing-Prompting. Metode penelitian yang digunakan adalah metode kuasi eksperimen. Instrumen yang digunakan berbentuk soal uraian, angket, dan lembar observasi. Materi yang digunakan adalah Persamaan Linear Dua Variabel (PLDV). Populasi penelitian ini yaitu seluruh siswa kelas VIII di SMPN 2 Garut tahun ajaran 2015/2016 dengan sampel kelas yang dipilih yaitu kelas VIII-D dan kelas VIII-E dengan jumlah masing-masing 36 siswa. Dari hasil penelitian, diperoleh kemampuan awal dan kemampuan akhir siswa menghasilkan pencapaian kemampuan pemecahan masalah matematis yang sama, namun peningkatan kemampuan pemecahan masalah matematis pada kelas AIR mendapatkan peningkatan yang sedang, sedangkan pada kelas Probing-Prompting mendapatkan peningkatan yang tinggi. Adapun sikap siswa terhadap kedua model pembelajaran menghasilkan respon yang sama yaitu tergolong baik.

Kata Kunci: Pemecahan masalah matematis, AIR, Probing-Prompting.
\end{abstract}

\begin{abstract}
Mathematics is still considered difficult for many students. This leads to students' mathematical problem solving skill remains low. One of reasons is the implementation of inappropriate learning model. Therefore, this study aims to analyze the differences of students' achievement and quality in mathematical problem solving skill enhancement as well as students' attitudes between those who received Auditory Intellectually Repetition (AIR) cooperative learning and those who received Probing-Prompting type. The research method used in this study was quasi-experimental method. Meanwhile, the research instruments used in this study were test, questionnaire, and observation sheet. Material used was the linear equation of two variables (PLDV). The population in this study was all VIII-grade students in Garut Junior High School academic year 2015/2016 with two classes selected as sample. The classes used as sample were VIII-D class and VIII-E class with 36 students respectively for each class. Based on the results of this study, it was found that the students' prior and final mathematical problem skills produced similar achievement. However, the increase of students' mathematical problem solving skills in AIR class achieved medium increase. Meanwhile, in Probing-Prompting class the increase was high. Then, students' attitudes towards both learning models produced similar responses. The responses could be categorized as good.

Keyword: mathematical problem solving, AIR, and Probing-Prompting
\end{abstract}




\section{Pendahuluan}

Pemecahan masalah matematis merupakan salah satu kemampuan yang dirasakan sangat penting, sehingga harus dikuasai oleh siswa khususnya siswa sekolah menengah agar dapat memecahkan masalahnya dalam kehidupan sehari-hari. Setiap orang khususnya para siswa dalam proses pembelajaran matematika pasti mempunyai masalah tersendiri. Masalah adalah kesenjangan antara harapan dan kenyataan. [1] mengemukakan bahwa, Masalah adalah penyimpangan antara yang diharapkan dengan kejadian atau kenyataan dan Proses pemecahan masalah matematis berbeda dengan proses menyelesaikan soal matematika. Menyelesaikan soal atau tugas matematis belum tentu sama dengan memecahkan masalah matematis... Suatu tugas matematis digolongkan sebagai masalah matematis apabila tidak dapat segera diperoleh cara menyelesaikannya namun harus melalui beberapa kegiatan lainnya yang relevan. Oleh karena itu, kemampuan pemecahan masalah matematis siswa sangat perlu untuk dikembangkan.

Menurut Cagne [2] mengemukakan bahwa, "Pemecahan masalah adalah tipe belajar yang tingkatnya paling tinggi dan kompleks dibandingkan dengan tipe belajar lainnya". "Pemecahan masalah sebagai suatu usaha mencari jalan keluar dari suatu kesulitan guna mencapai suatu tujuan yang tidak begitu segera dapat dicapai." (Polya dalam [3]). Susilawati mengartikan, "Pemecahan masalah dalam matematika adalah aktivitas untuk menyelesaikan masalah yang cara penyelesaiannya belum mempunyai prinsip (aturan, rumus, dalil) tertentu yang segera dapat dipergunakan untuk menemukan jawaban terhadap masalah tersebut". [3]

Lebih lanjut, Soemarmo mengartikan bahwa, "Pemecahan masalah dapat berupa menciptakan ide baru, menemukan teknik atau produk baru, bahkan dalam pembelajaran matematika pemecahan masalah mempunyai interpretasi berbeda. [3] Misalnya menyelesaikan soal cerita, soal yang tidak rutin, dan mengaplikasikan matematika dalam kehidupan sehari-hari".

Proses pemecahan masalah matematis merupakan kemampuan yang sangat penting yang harus dikuasai oleh siswa terutama siswa sekolah menengah. Cooney mengemukakan bahwa, "Pemilikan kemampuan masalah membantu siswa berpikir analitik dalam mengambil keputusan dalam kehidupan sehari-hari dan membantu meningkatkan kemampuan berpikir kritis dalam menghadapi situasi baru". [4]

Hendriana dan Soemarmo menyatakan bahwa, Pemecahan masalah matematis sebagai suatu proses meliputi beberapa kegiatan yaitu: mengidentifikasi kecukupan unsur untuk penyelesaian masalah, memilih dan melaksanakan strategi untuk menyelesaikan masalah, melaksanakan perhitungan, dan menginterpretasi solusi terhadap masalah semula dan memeriksa kebenaran solusi. [4]

Ada beberapa kemampuan pemecahan masalah yang harus ditumbuhkan menurut Dodson dan Hollander, diantaranya: [4] 
1. Kemampuan mengerti konsep dan istilah matematika.

2. Kemampuan untuk mencatat kesamaan, perbedaan, dan analogi.

3. Kemampuan untuk mengidentifikasi elemen terpenting dan memilih prosedur yang benar.

4. Kemampuan untuk memilih hal yang tidak berkaitan.

5. Kemampuan untuk menganalisa.

6. Kemampuan untuk memvisualisasikan dan menginterpretasikan kualitas.

7. Kemampuan untuk memperumum berdasarkan beberapa contoh.

8. Kemampuan untuk berganti metode yang telah diketahui. Mempunyai kepercayaan diri yang cukup.

Dalam pemecahan masalah biasanya ada 5 langkah yang harus dilakukan menurut Ruseffendi, diantaranya: [2]

1. Menyajikan masalah dalam bentuk yang lebih jelas;

2. Menyatakan masalah dalam bentuk yang operasional (dapat dipecahkan);

3. Menyusun hipotesis-hipotesis alternatif dan prosedur kerja yang diperkirakan baik untuk dipergunakan dalam memecahkan masalah itu;

4. Mengetes hipotesis dan melakukan kerja untuk memperoleh hasilnya (pengumpul-an data, pengolahan data, dan lain-lain);

5. Memeriksa kembali (mengecek) apakah hasil yang diperoleh itu benar; mungkin memilih pula pemecahan yang paling baik.

Soemarmo menyatakan bahwa indikator kemampuan pemecahan masalah sebagai berikut: [5]
1. Mengidentifikasi kecukupan data untuk pemecahan masalah.

2. Membuat model matematika dari suatu situasi atau masalah sehari-hari dan menyelesaikannya.

3. Memilih dan menerapkan strategi untuk menyelesaikan masalah matematika atau di luar matematika.

4. Menjelaskan atau menginterpretasi hasil sesuai permasalahan asal serta memeriksa kebenaran hasil atau jawaban.

5. Menerapkan matematika secara bermakna.

Perkembangan model pembelajaran matematika di Indonesia masih memprihatinkan, karena rendahnya penguasaan teknologi dan kemampuan sumber daya manusia Indonesia untuk berkompetensi secara global. Arradian menyatakan bahwa, "Berdasarkan data Trends in International Mathematics and Science Study (TIMSS) pada tahun 2011, pembelajaran matematika di Indonesia berada di peringkat 38 dari 42 negara. Jauh tertinggal dibanding Singapura, Thailand, dan Malaysia". [6] "Pembelajaran matematika berada di peringkat bawah karena metode pembelajaran kelas-kelas di Indonesia monoton dan membuat bosan." [7]

Hal tersebut menjadi motivasi bagi banyak peneliti dan guru untuk terus mengembangkan dan memilih modelmodel pembelajaran yang dianggap mampu meningkatkan motivasi belajar siswa serta meningkatkan kemampuan matematis siswa yang menjadi tujuan pembelajaran matematika. Model-model pembelajaran yang dikembangkan itu juga 
diharapkan dapat meningkatkan kualitas dan keterampilan mengajar guru, serta dapat meningkatkan prestasi belajar siswa.

Model pembelajaran yang diduga akan mampu meningkatkan kemampuan pemecahan masalah matematis serta sikap siswa terhadap model pembelajaran matematika khususnya yaitu model pembelajaran kooperatif tipe Auditory Intellectually Repetition (AIR) dan model pembelajaran kooperatif tipe ProbingPrompting. Kedua model pembelajaran ini diduga mampu meningkatkan kemampuan pemecahan masalah matematis siswa.

\section{A. Model pembelajaran kooperatif tipe Auditory Intellectually Repetition (AIR)}

Suherman mengungkapkan, Model pembelajaran AIR adalah model pembelajaran yang menganggap bahwa suatu pembelajaran akan efektif jika memperhatikan tiga hal yaitu Auditory, Intellectually, and Repetition. Auditory berarti indera telinga digunakan dalam belajar dengan cara menyimak, berbicara, presentasi, argumentasi, mengemukakan pendapat, dan menanggapi [8]. Intellectually berarti kemampuan berpikir perlu dilatih melalui latihan bernalar, mencipta, memecahkan masalah, mengkontruksi, dan menerapkan. Repetition berarti pengulangan diperlukan dalam pembelajaran agar pemahaman lebih mendalam dan lebih luas, peserta didik perlu dilatih melalui pengerjaan soal, pemberian tugas, dan kuis.

\section{B. Auditory}

Dave Meier menyatakan bahwa, "Pikiran auditoris lebih kuat daripada yang kita sadari [9]. Telinga kita terus menerus menangkap dan menyimpan informasi auditoris, bahkan tanpa kita sadari. Belajar auditoris merupakan cara belajar standar bagi masyarakat”. Hal lain, Huda mengemukakan bahwa, "Gaya belajar auditorial adalah gaya belajar yang mengakses segala jenis bunyi dan kata, baik yang diciptakan maupun diingat [9]. Karena siswa auditoris lebih mudah belajar dengan cara berdiskusi dengan orang lain....".

\section{Intellectually}

"Intelektualitas adalah sarana penciptaan makna, sarana yang digunakan manusia untuk berpikir, menyatukan gagasan, dan menciptakan jaringan saraf. Proses ini tentu tidak berjalan dengan sendirinya, ia dibantu oleh faktor mental, fisik, emosional, dan intuitif". [9]

\section{Repetition}

Repetisi mempunyai arti pengulangan. Dalam pembelajaran repetisi merupakan pendalaman, perluasan, dan pemantapan siswa dengan memberinya tugas atau kuis. Huda menyatakan, "Jika guru menjelaskan suatu unit pelajaran, ia harus mengulangnya dalam beberapa kali kesempatan [9]. Ingatan siswa tidak selalu stabil. Mereka tak jarang mudah lupa. Untuk itulah guru perlu membantu mereka dengan mengulangi pelajaran yang sedang atau sudah dijelaskan". "Pelajaran yang diulang akan memberi tanggapan yang jelas dan tidak mudah dilupakan, sehingga 
siswa bisa dengan mudah memecahkan masalah. Ulangan semacam itu bisa diberikan secara teratur, pada waktu-waktu tertentu, atau tiap unit diberikan, maupun secara insidental jika dianggap perlu." (Slamet dalam [9]).

\section{E. Model Pembelajaran Kooperatif Tipe Probing-Prompting}

Pembelajaran Probing-Prompting sangat erat kaitannya dengan pertanyaanpertanyaan. Menurut arti kata, probing adalah penyelidikan dan pemeriksaan, sedangkan prompting adalah mendorong atau menuntun. Suherman menyatakan bahwa, "Pembelajaran probing-prompting adalah pembelajaran dengan menyajikan serangkaian pertanyaan yang sifatnya menuntun dan menggali gagasan siswa sehingga dapat melejitkan proses berpikir yang mampu mengaitkan pengetahuan dan pengalaman siswa dengan pengetahuan baru yang sedang dipelajari”. [9]

Pembelajaran probing-prompting sangat erat kaitannya dengan pertanyaan. Pertanyaan-pertanyaan yang dilontarkan pada saat pembelajaran ini disebut probing question. "Probing question adalah pertanyaan yang bersifat menggali untuk mendapatkan jawaban lebih dalam dari siswa yang bermaksud untuk mengembangkan kualitas jawaban, sehingga jawaban berikutnya lebih jelas, akurat, dan beralasan." (Suherman, dkk. dalam [9]).

Probing question dapat memotivasi siswa untuk memahami suatu masalah dengan lebih mendalam sehingga siswa mampu mencapai jawaban yang dituju. Selama proses pencarian dan penemuan jawaban atas masalah tersebut, mereka berusaha menghubungkan pengetahuan dan pengalaman yang telah dimiliki dengan pertanyaan yang akan dijawab.

Proses tanya jawab dalam pembelajaran dilakukan dengan menunjuk siswa secara acak sehingga setiap siswa mau tidak mau harus berpartisipasi aktif. Siswa tidak bisa menghindar proses pembelajaran, karena setiap saat ia bisa dilibatkan dalam proses tanya jawab. Berdasarkan penelitian Priatna, "Proses probing dapat mengaktifkan siswa dalam belajar yang penuh tantangan, sebab ia menuntut konsentrasi dan keaktifan". [9]

\section{Il. Metode}

Sehubungan dengan permasalahan yang diteliti maka metode penelitian yang sesuai adalah metode kuasi eksperimen. Perlakuan yang diberikan pada penelitian ini adalah pembelajaran yang mendapatkan model pembelajaran kooperatif tipe Auditory Intellectually Repetition dan model pembelajaran kooperatif tipe Probing-Prompting. Dalam penelitian ini, sebelum diberikan pembelajaran siswa diberi tes awal (Pretest) dan setelah diberikan pembelajaran siswa diberi tes akhir (Posttest).

Populasi dalam penelitian yaitu seluruh siswa kelas VIII di sebuah SMP Negeri Garut tahun ajaran 2015/2016 yang berjumlah 390 siswa diambil sampel dua kelas yang dipilih oleh guru mata pelajaran, yaitu kelas yang menggunakan model pembelajaran kooperatif tipe Auditory Intellectually Repetition dan kelas kelas yang menggunakan model 
pembelajaran kooperatif tipe ProbingPrompting dengan banyaknya siswa masing-masing 36 siswa.

Analisis data dilakukan untuk memberikan gambaran terhadap data yang telah dikumpulkan dari hasil penelitian. Hal ini dimaksudkan untuk mencari kesimpulan dan menguji hipotesis. Data yang dianalisis diperoleh dari hasil pretest, posttest, dan angket. Pretest dilakukan pada kedua kelas eksperimen untuk menganalisis kemampuan awal siswa sebelum diberikan pembelajaran. Dalam menganalisis perbedaan kemampuan akhir pemecahan masalah matematis, kedua kelas diberi posttest. Analisis data kualitatif berkenaan dengan pengukuran non tes. Adapun yang dianalisis sebagai data kualitatif yaitu: angket, lembar observasi keterlaksanaan model pembelajaran yang digunakan, dan lembar observasi sikap siswa. Angket dilakukan untuk mengukur respon siswa terhadap model pembelajaran yang diberikan.

\section{Hasil dan Pembahasan}

Secara deskripsi, hasil penelitian disajikan pada tabel berikut:

Tabel 1.

Hasil Penelitian

\begin{tabular}{|c|c|c|c|c|}
\hline \multirow[t]{2}{*}{ Keterangan } & \multicolumn{2}{|c|}{ Kelas $A I R$} & \multicolumn{2}{|c|}{$\begin{array}{c}\text { Kelas Probing- } \\
\text { Prompting }\end{array}$} \\
\hline & Pretest & Posttest & Pretest & Posttest \\
\hline Jumlah Siswa & 34 & 34 & 30 & 30 \\
\hline Skor Ideal & 4,00 & 4,00 & 4,00 & 4,00 \\
\hline Nilai Terbesar & 1,11 & 4,00 & 1,78 & 4,00 \\
\hline Nilai Terkecil & 0,00 & 0,56 & 0,00 & 0,44 \\
\hline Rata-rata & 0,42 & 2,09 & 0,44 & 2,33 \\
\hline Simpangan Baku & 0,30 & 0,93 & 0,40 & 1,23 \\
\hline $\begin{array}{l}\text { Rata-rata Persentase } \\
\text { Nilai dari Skor Ideal }\end{array}$ & $10,50 \%$ & $52,25 \%$ & $11,00 \%$ & $58,25 \%$ \\
\hline
\end{tabular}

Dari hasil analisis data kesamaan kemampuan awal pemecahan masalah matematis, dengan menggunakan taraf signifikan $(\alpha)$ sebesar 5\%, diketahui normalitas distribusi data tidak berdistribusi normal. Dengan menggunakan uji Mann Whitney, diperoleh nilai $z_{\text {tabel }}=1,96$; dan nilai $z_{\text {hitung }}=$ 0,19 maka pengujian menerima Ho. Dari hal tersebut, dapat disimpulkan bahwa tidak terdapat perbedaan kemampuan awal yang signifikan antara siswa yang mendapatkan model pembelajaran kooperatif tipe Auditory Intellectually Repetition (AIR) dengan tipe ProbingPrompting.

Setelah perlakuan diberikan, kemudian dilakukan tes akhir kemampuan pemecahan masalah matematis yang menunjukkan pencapaian kemampuan pemecahan masalah. Dari hasil analisis data perbedaan pencapaian kemampuan akhir kedua kelas pada penelitian ini, diketahui normalitas distribusi data keduanya berdistribusi normal dan mempunyai varians yang homogen, serta diperoleh nilai $\mathrm{t}_{\text {hitung }}=-0,88$ dengan $\mathrm{t}_{\text {tabel }}=$ 2,00; maka Ha ditolak, sehingga dapat disimpulkan bahwa tidak terdapat perbedaan pencapaian kemampuan pemecahan masalah matematis yang signifikan antara siswa yang mendapatkan model pembelajaran kooperatif tipe Auditory Intellectually Repetition (AIR) dengan tipe Probing-Prompting.

Adapun mengenai hasil deskripsi peningkatan kemampuan pemecahan masalah matematis yang diperoleh dari hasil perhitungan gain ternormalisasi didapat hasil dalam bentuk persentase, sebagai berikut: 
Tabel 2.

Persentase Kualitas Peningkatan Kemampuan Pemecahan Masalah Matematis Kelas AIR Setelah Diberikan Pembelajaran

\begin{tabular}{|ccc|}
\hline Kategori & Banyak Siswa & Persen \\
\hline Tinggi & 5 & 14,71 \\
\hline Sedang & 20 & 58,82 \\
\hline Rendah & 9 & 26,47 \\
\hline Jumlah & 34 & 100 \\
\hline
\end{tabular}

Dari Tabel 2, diketahui bahwa lebih dari setengahnya, peningkatan kemampuan pemecahan masalah siswa meningkat sebesar 58,82\%, sedangkan untuk kategori tinggi $14,71 \%$, namun masih ada yang peningkatan kemampuan pemecahan masalahnya tergolong rendah yaitu sebesar 26,47\%.

Mengenai hasil deskripsi peningkatan kemampuan pemecahan masalah matematis siswa yang mendapat pembelajaran tipe Probing-Prompting yang diperoleh dari hasil perhitungan gain ternormalisasi didapat hasil dalam bentuk persentase, sebagai berikut:

Tabel 3.

Persentase Kualitas Peningkatan Kemampuan Pemecahan Masalah Matematis Kelas Probing-Prompting

\begin{tabular}{|ccc|}
\hline Kategori & Banyak Siswa & Persen \\
\hline Tinggi & 12 & 40,00 \\
\hline Sedang & 11 & 36,67 \\
\hline Rendah & 7 & 23,33 \\
\hline Jumlah & 30 & 100 \\
\hline
\end{tabular}

Dari Tabel 3, diperoleh informasi bahwa sebanyak 40,00\% siswa mengalami peningkatan kategori tinggi, sedangkan untuk kategori sedang sebanyak 36,67\%, dan kategori rendah mendapatkan 23,33\%. dengan banyak siswa 7 orang.

Adapun hasil observasi sikap siswa selama pembelajaran pada Model Pembelajaran Kooperatif Tipe Auditory Intellectually Repetition disajikan pada gambar 1 berikut.

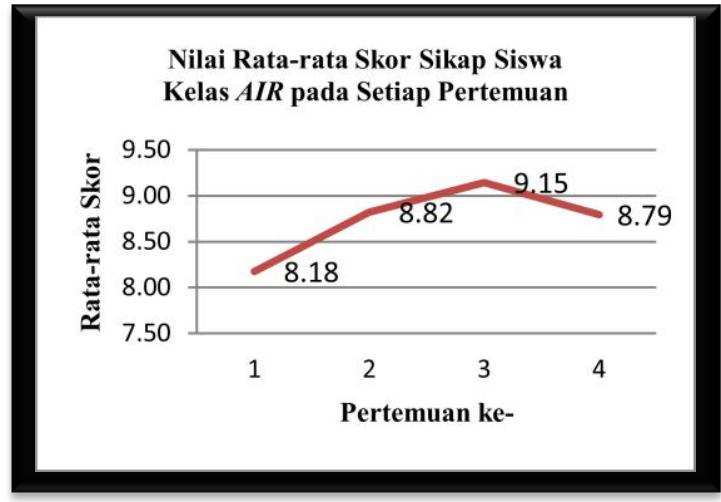

Gambar 1. Nilai Rata-rata Skor Sikap Siswa Kelas AIR pada Setiap Pertemuan

Berdasarkan Gambar 1, sikap siswa pada pertemuan pertama sampai pertemuan ketiga mengalami peningkatan, namun saat pertemuan keempat sikap siswa mengalami penurunan. Hal tersebut dikarenakan motivasi belajar siswa yang selalu tidak stabil sehingga pencapain skor pada setiap indikator mendapatkan skor yang rendah.

Secara umum, hasil analisis data skala sikap siswa terhadap model pembelajaran kooperatif tipe Auditory Intellectually Repetition mendapatkan tanggapan sikap yang baik. Dengan demikian dapat disimpulkan bahwa interpretasi skala sikap siswa terhadap pembelajaran dengan menggunakan model pembelajaran kooperatif tipe Auditory Intellectually Repetition dengan tipe Probing-Prompting mendapatkan tanggapan yang baik dari sikap para siswa.

Mengenai hasil observasi mengenai keterlaksanaan kegiatan inti model pembelajaran Kooperatif Tipe Auditory Intellectually Repetition, persentase keterlaksanaan kegiatan inti model pembelajaran kooperatif tipe Auditory Intellectually Repetition secara keseluruhan dari pertemuan pertama sampai terakhir mencapai $100 \%$, namun pada tahap Auditory, yaitu pada pertemuan 
pertama kegiatan guru memberikan kesempatan kepada kelompok lain untuk bertanya dan mengemukakan pendapatnya tidak terlaksana sehingga hanya mencapai $75 \%$.

Adapun hasil observasi sikap siswa selama pembelajaran pada Model Pembelajaran Kooperatif Tipe ProbingPrompting disajikan pada gambar 2.

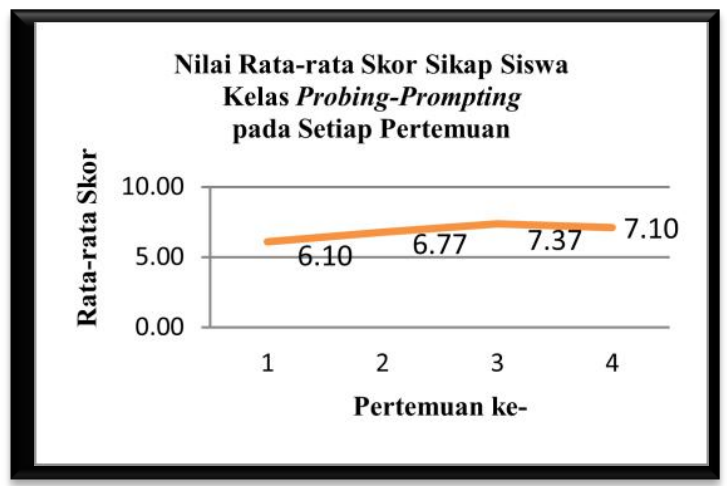

Gambar 2. Nilai Rata-rata Skor Sikap Siswa Kelas Probing-Prompting pada Setiap Pertemuan

Berdasarkan Gambar 2, sikap siswa pada pertemuan pertama sampai pertemuan ketiga mengalami peningkatan, namun saat pertemuan keempat sikap siswa mengalami penurunan. Hal tersebut dikarenakan motivasi belajar siswa yang selalu tidak stabil sehingga pencapain skor pada setiap indikator mendapatkan skor yang rendah dan tingkat kesulitan materi pada pertemuan keempat semakin sulit sehingga mempengaruhi rata-rata skor sikap siswa.

Begitu pula sikap siswa secara umum terhadap pembelajaran menggunakan model pembelajaran kooperatif tipe Probing-Prompting mendapatkan tanggapan sikap yang baik.

Pada Model Pembelajaran Kooperatif Tipe Probing-Prompting, persentase keterlaksanaan kegiatan inti model pembelajaran kooperatif tipe ProbingPrompting secara keseluruhan dari pertemuan pertama sampai terakhir mencapai 100\%, hal ini berarti guru melaksanakan proses pembelajaran dengan baik.

Berdasarkan hasil pengamatan peneliti selama pelaksanaan penelitian berlangsung, ada beberapa penyebab tidak terjadinya perbedaan kemampuan pemecahan masalah matematis diantara kedua tipe pembelajaran tersebut. Perbedaan dalam hal ini bersifat positif, diantaranya sebagai berikut:

1. Pada kelas $A I R$, siswa berusaha sendiri mengerjakan contoh soal sesuai dengan kemampuannya kemudian guru memberikan penjelasan. Pada kelas Probing-Prompting, siswa berusaha mengerjakan contoh soal secara berkelompok kemudian guru memberikan penjelasan.

2. Pada kelas AIR, siswa mempresentasikan hasil diskusinya dan kelompok lain menanggapi. Pada kelas Probing-Prompting guru yang menggali informasi dari siswa mengenai hasil diskusinya.

3. Pada kelas AIR, siswa memiliki keberanian berpendapat dari kegiatan presentasi dan menyanggah pendapat temannya. Pada kelas ProbingPrompting siswa memiliki keberanian mengemukakan jawaban dari pertanyaan yang diberikan oleh guru.

4. Kelas AIR dan kelas ProbingPrompting memiliki kelebihan masingmasing, diantaranya:

Kelebihan model pembelajaran kooperatif tipe Auditory Intellectually Repetition menurut Sihalolo:

1. Melatih pendengaran dan keberanian siswa untuk mengungkapkan pendapat (Auditory).

2. Melatih siswa untuk memecahkan masalah secara kreatif (Intellectually).

3. Melatih siswa untuk mengingat kembali tentang materi yang telah dipelajari (Repetition). 
4. Siswa menjadi lebih aktif dan kreatif.

Kelebihan dari model pembelajaran kooperatif tipe Probing-Prompting menurut Suhendra (2012: 21) diantaranya:

1. Mendorong siswa aktif berfikir.

2. Memberi kesempatan kepada siswa untuk menanyakan hal-hal yang kurang jelas sehingga guru dapat menjelaskan kembali.

3. Perbedaan pendapat antara siswa dapat dikompromikan atau diarahkan.

4. Pertanyaan dapat menarik dan memusatkan perhatian siswa, sekalipun ketika itu siswa sedang ribut, yang mengantuk kembali tegar dan hilang kantuknya.

5. Sebagai cara meninjau kembali (review) bahan pelajaran yang lampau.

6. Mengembangkan keberanian dan keterampilan siswa dalam menjawab dan mengemukakan pendapat.

Dari hasil penelitian, ditemukan bahwa kegiatan pembelajaran menggunakan model pembelajaran kooperatif tipe Auditory Intellectually Repetition dengan Tipe ProbingPrompting tidak terdapat perbedaan yang signifikan. Hal itu dapat dilihat dari proses pembelajaran serta dari hasil rata-rata nilai yang didapat siswa pada tes akhir.

\section{Penutup}

Berdasarkan hasil penelitian dan pembahasan secara keseluruhan terhadap data penelitian, maka sesuai rumusan masalah peneliti memperoleh kesimpulan, yaitu tidak terdapat perbedaan kemampuan pemecahan masalah matematis antara siswa yang mendapatkan model pembelajaran kooperatif tipe Auditory Intellectually Repetition dengan tipe Probing-Prompting.

Kualitas peningkatan kemampuan pemecahan masalah matematis siswa dengan menggunakan model pembelajaran kooperatif tipe Auditory Intellectually Repetition mendapatkan peningkatan yang sedang, sedangkan dengan model pembelajaran kooperatif tipe ProbingPrompting mendapatkan peningkatan yang tinggi.

Sikap siswa terhadap pembelajaran dengan menggunakan model pembelajaran kooperatif tipe Auditory Intellectually Repetition menunjukkan sikap baik, sedangkan dengan model pembelajaran kooperatif tipe Probing-Prompting menunjukkan sikap baik.

Penelitian ini dilakukan pada subjek yang terbatas, yaitu pada salah satu SMPN yang berada di Kab. Garut kelas VIII dengan pokok bahasan Persamaan Linear Dua Variabel (PLDV). Supaya hasil penelitian lebih umum, disarankan bagi para peneliti lain untuk melakukan penelitian tentang model pembelajaran kooperatif tipe Auditory Intellectually Repetition dan tipe Probing-Prompting untuk meningkatkan kemampuan pemecahan masalah matematis siswa lebih lanjut dengan mengambil subjek, sekolah, jenjang tingkatan serta materi yang berbeda, juga tidak hanya berfokus pada kemampuan pemecahan masalah matematis saja, tetapi pada kemampuan matematis yang lainnya dan harus memenuhi kriteria ketuntasan belajar.

\section{DAFTAR PUSTAKa}

[1] Mahmud, Metode Penelitian Pendidikan, Bandung: CV. Pustaka Setia, 2011.

[2] H. E. T. Ruseffendi, Pengajaran Matematika untuk Meningkatkan 
CBSA, Bandung: PT. Tarsito Bandung, 2006.

[3] W. Susilawati, Belajar dan Pembelajaran Matematika, Bandung: CV. Insan Mandiri, 2014.

[4] H. Hendriana dan U. Soemarmo, Penilaian Pembelajaran Matematika, Bandung: PT. Refika Aditama, 2014.

[5] U. Soemarmo, Berpikir dan Disposisi Matematik serta Pembelajarannya. Bandung: Jurusan Pendidikan Matematika FPMIPA UPI, 2013.

[6] D. Arradian, (2015, Juni). Ajarkan Bahasa Matematika Mudah [Online]. Tersedia: http://www.koransindo.com/read/994672/152/ajarkanbahasa-matematika-mudah1430189249.

[7] R. Keswara, (2015, Juli). Pembelajaran matematika di Indonesia masuk peringkat rendah [Online]. Tersedia: http://nasional.sindonews.com/read/80 4091/15 pembelajaran-matematika-diindonesia-masuk-peringkat-rendah1384111047. [16, 2013.

[8] Rusman, Model-Model Pembelajaran, Jakarta: PT. Raja Grafindo Persada, 2012.

[9] M. Huda, Model-model Pengajaran dan Pembelajaran, Yogyakarta: Pustaka Pelajar, 2013.

[10] Sihalolo, 2012 